\title{
The interrelationship between cognitive control and academic success of first-year students: An interdisciplinary study
}

\author{
Svetlana N. Kostromina*, Nadezhda A. Mkrtychian, \\ Diana M. Kurmakaeva, Daria S. Gnedykh \\ Saint Petersburg State University, Saint Petersburg, Russia \\ *Corresponding author. E-mail: nadezhda.mkrtichyan@gmail.com
}

Background. Though many Russian and foreign studies have been devoted to the study of self-control in educational activity, most of the research has been limited to the use of questionnaires or psychodiagnostic methods. The neurophysiological mechanisms underlying the process of cognitive control in the context of learning have still not been sufficiently understood, despite the obvious significance of controlling action for academic success.

Objective. The purpose of this study is to identify the psychological and neurophysiological features of cognitive control in the process of learning activity, for students with different levels of academic success.

Design. This study investigates the control function in first-year students who have varying degrees of academic success. The research design is interdisciplinary and integrates three different approaches: the neurophysiological, psychological, and pedagogical. In the empirical part, 31 first-year students at Saint Petersburg State University ( $\mathrm{SPSSU})$ participated in the research. We measured the personal characteristics of the subjects (using the five-factor personality questionnaire as modified by A.B. Khromov), their self-management ability (Peysakhov's SMA test), characteristics of the event-related potentials of the brain in response to presentation of stimuli in the solving of problems that require searching for an error in a word (electroencephalographic method), response time, and number of errors and corrections. Four types of stimuli were used: the correct spelling of a word, the replacement of a letter with one that is written similarly or sounds similar, or by one that is not similar. The indicators used to measure academic success were the results of the Unified State Examination (USE) and the first (winter) term of the 2016-17 academic year. The data were analyzed by correlation analysis and analysis of variance.

Results. Comparison of groups of students with lower and higher levels of academic success showed significant differences in all the measured groups of variables - personality traits (Emotionality-Restraint factor), components of the system of self-management (Goal-Setting and Forecasting scales), behavioral data from the experiment (number of corrections), and neurophysiological indicators of cognitive control (the components P200, N200, P300, and N400). The results of the study revealed that students 
with greater academic success are characterized by less emotionality, a higher capability for goal-setting, and a lower capability for forecasting, as well as greater attention and greater engagement in solving the task of finding mistakes. Such students flexibly distribute their efforts depending on the difficulty of the task and are less likely than the less successful students to change their initial answer to the experimental task.

Conclusion. A high level of development of the self-regulation and self-management system potentially improves the process of finding an error which is necessary for better academic success.

Keywords: cognitive control, self-control, event-related potentials, academic success

\section{Introduction}

Interdisciplinary research is becoming increasingly popular in modern human science, allowing the study of the object of interest from different vantage points and with different structural interrelationships with other objects and phenomena. Such an integrated approach makes possible a more holistic view of the person as the subject of cognition. A special place in the human sciences is occupied by neuroscience, which combines the most significant achievements in psychology, physiology, education, economics, and so forth. At the same time researchers who integrate knowledge from different domains face a number of difficulties associated in particular with confusion in terminology, lack of a common conceptual framework, and different paradigms for constructing empirical and experimental studies.

The study of control mechanisms is a subject of research in many scientific fields: physiology, psychology, pedagogy, etc. The importance of such research is mediated by the effectiveness of human activity. The function of control is to achieve goals, manage one's actions on the path from the goal to a result, correct in a timely way the deviations and disturbances of activity that arise. In psychology, the controlling function of the subject is mainly revealed through the concept of self-control; in pedagogy it is through self-control and control of educational activities; and for modern physiology, the closest term is "cognitive control." We will also use that term when describing the results of the experimental part of the study.

\section{Control as a subject of study in education, psychology, and physiology}

In Russian psychological research, self-control is usually defined as a regulatory function, the ability to restrain and suppress primitive urges and emotions and subordinate them to distant or higher goals (Rean, Ed., 2002).

In education, self-control is the most important link in the structure of learning activity. The self-regulation of any educational activities is acquired only through processes of control that perform the function of regulation (Elkonin, 1974; Davydov, 1986).

In Russian physiology, the mechanism of control over one's actions and their evaluation is described by P.K. Anokhin's functional system, in which any information about a process and the result of an action constitutes reverse afferentation or feedback, which controls, manages, and regulates of actions. The process of comparing the "image of the result of action" (Anokhin, 1975) or "model of the desired future" (Bernstein, 1990) with real information about an action takes place, 
according to Anokhin, due to the "action result acceptor." If these are consistent, there is a basis to continue the action, but if they diverge, the action has to be adjusted. In the structure of the controlling functions, implementation of activities is provided by three components (links): the image of the desired result of the action, its juxtaposition or comparison with real action, a decision on whether to continue or adjust the action. Each action of these links is controlled by multiple feedback paths. Self-control is a complex process, involved in all kinds of conscious activity, which makes it the most critical component of the human psyche, allowing us to consider the person as a self-regulating, self-improving, and self-educating system (Pavlov, 1973).

In foreign neuropsychological studies, cognitive control is described by executive functions. Executive functions are high-level cognitive functions, mediated primarily by the frontal lobes (Stuss \& Knight, 2002). Executive functions include a range of cognitive processes and behavioral abilities required for control of attention, temporal organization of responses, planning to achieve goals, ability to assimilate and use the information in long-term memory, controlling and monitoring the current situation (Friedman \& Miyake, 2017; Lesh et al., 2013; Diamond, 2013).

Many Russian and foreign studies have been devoted to the study of self-control in educational activity; however most of the research has been limited to the use of questionnaires or psychodiagnostic methods. The neurophysiological mechanisms underlying the process of cognitive control in the context of learning have still not been sufficiently understood, despite the obvious significance of controlling action for academic success.

This matter is partially solved by defining the role of inhibitory control in academic achievement (Espy et al., 2004; Cartwright, 2012; Gilmore \& Cragg, 2014). Findings suggest that in primary school, inhibitory control and working memory contribute significantly to the performance of mathematical and reading assignments (Thorell, 2007; Welsh et al., 2010; Steele et al., 2012), and at the ages of 11 and 14, they determine the results of school tests in English, mathematics, and science (St Clair-Thompson \& Gathercole, 2006; Nunes et al., 2012).

There is still insufficient data reported in the literature on the interrelationship between academic success and higher-order cognitive control associated not only with inhibition of undesired impulses in response to the presentation of artificial competing stimuli (inhibitory control), but also with control over the execution of tasks without the interruption of learning activity.

Study of the neuronal basis of cognitive control during learning activities will allow us to achieve a new level of understanding of the mechanisms that determine its successful application to solving learning tasks, and comparing the effects of performing tasks on cognitive control with the psychological characteristics of students and their objective academic performance will allow us to extrapolate the data thus obtained to psychological and pedagogical practice. The potential of interdisciplinary research to solve problems of education seems to be most promising (Kostromina et al., 2015).

Thus it is extremely important today to search for the interrelationships among the neurophysiological characteristics of cognitive control in educational activities, the psychological personality traits of students, and objective indicators of their academic success. 
The purpose of this study is to identify the psychological and neurophysiological features of cognitive control in the process of learning activity, for students with different levels of academic success.

\section{Method}

Empirical methods were used for the comprehensive study of control processes, corresponding to different levels of controlling functions:

1) neurophysiological evaluation - electroencephalography (the method of event-related potentials, ERPs) and measurement of reaction time;

2) psychological evaluation - psychological diagnostics of personal qualities that are based on volitional and emotional regulation; the degree of development of the system of self-management, including self-control (the five-factor personality questionnaire - the Big Five as modified by A.B. Khromov and the methodology of Peysakhov's "Self-Management Ability" test, the SMA);

3) pedagogical evaluation - questionnaires (general information about respondents, including the results of entrance examinations and their first [winter] term at university) and analysis of activities performed (success in experimental problems of searching for spelling errors).

An electroencephalogram (EEG) was performed using an Mitsar-EEG-202 digital electroencephalograph (produced by OOO Mitsar, St. Petersburg), the MCScap electrode cap, and the WinEEG software package. We used 19 electrodes placed on the scalp according to the international 10-20 system, at leads Fp1, Fp2, F7, F3, Fz, F4, F8, T3, C3, Cz, C4, T4, T5, P3, Pz, P4, T6, O1, O2. Reference electrodes were placed on the earlobes, and a ground electrode on the forehead. A high-pass filter, on which the EEG registration is performed at $0.1(1.6 \mathrm{~Hz})$; a low pass-filter at 30 $\mathrm{Hz}$. A monopolar method of registering the EEG was used; during the study, an oculogram (EOG) was recorded.

Registration of the EEG was performed during the task of searching for mistakes.

\section{Stimuli}

As stimulus material, we used 7-9-letter high-frequency Russian words, spelled correctly or with an error that substituted a letter with one that either sounds similar or looks similar, or with one that is not similar either in sound or appearance.

Russian words were chosen as stimulus words because checking the correctness of spelling is the most common learning activity; that is, it is naturally included in any learning situation for different subjects, starting from the first grade.

The type of controlling action was chosen taking into account that control always involves a process of checking against some model or standard - comparison of what is with what should be. In the case of checking the correct spelling of a word, a visual image of the word/letter, or a phonetic image (after all, when we check the text, we read it, that is, we say it to ourselves), or a rule of the Russian language can serve as a standard. 
The types of stimuli were developed based on the understanding that the control process is less familiar and therefore less automatic for an adult than is reading, which, in fact, is of an opposite nature. When we read, we do not look at each letter, but ignore possible deviations from the standard so as not to lose the thread of the narrative and the meaning of the text. Therefore text verification skills require further development. To choose the appropriate methods for this, it is necessary to determine whether the process of comparison with the standard is the same for different types of standards (visual or auditory). To address this question, we chose 4 types of stimuli for our study:

Type 1 - words that contain an error in which one of the letters is replaced with another that has a similar sound;

Type 2 - words that contain an error in which one letter is replaced with another that is not similar either in appearance or sound;

Type 3 - words that contain an error in which one letter is replaced with another that looks similar;

Type 4 - words without mistakes or typographical errors.

Words with an error because a letter has been replaced with one that sounds similar have to pass phonetic but not visual control; if a letter is replaced by a visually similar one, the opposite is the case. Typographical errors should cause a mismatch signal on both channels of verification, and words written according to the rules of the Russian language have to pass both types of control.

Examples of stimulus material of each type are shown in Table 1.

Table 1. Examples of Stimulus Material

\begin{tabular}{|c|c|c|c|c|}
\hline $\begin{array}{c}\text { Type of } \\
\text { stimulus }\end{array}$ & Type 1 & Type 2 & Type 3 & Type 4 \\
\hline Example & $\begin{array}{r}\text { церкофь } \\
\text { [tserkof'] } \\
\text { [correct word: } \\
\text { церковь - } \\
\text { tserkov' - church] }\end{array}$ & $\begin{array}{r}\text { просткй } \\
\text { [prostki] } \\
\text { [correct word: } \\
\text { простой - } \\
\text { prostoi - simple] }\end{array}$ & $\begin{array}{r}\text { инстигут } \\
\text { [instigut] } \\
\text { [correct word: } \\
\text { институт - } \\
\text { institut - institute] }\end{array}$ & $\begin{array}{r}\text { поднять } \\
\text { [podniat'] } \\
\text { [the spelling is } \\
\text { correct - to raise] }\end{array}$ \\
\hline
\end{tabular}

All four groups of stimuli were balanced according to the number of seven-, eight-, and nine-letter words. The total number of stimuli was 216 (18 in the pilot study and 198 in the main study), with an equal distribution of correctly spelled words (50\%) and of each of the types of errors (16.67\%).

\section{Procedure for presentation}

The stimulus words were presented in random order on a computer screen using the software PsychoPy2, version 1.82.01. The procedure for presentation of the stimuli is shown in Figure 1. Font - Times New Roman; color of letters - black; background - white. Each stimulus was presented for 1,500 ms, with an $800 \mathrm{~ms}$ pause between stimuli. During the pause, a sign in the shape of a cross was shown for $400 \mathrm{~ms}$, to focus the gaze. The subject was instructed to press one of the two 
keys, depending on whether the word was written correctly or not. The instruction was as follows: "Words will appear sequentially on the screen before you. If the word is spelled correctly, press -> (right arrow); if there is an error, press <- (left arrow). Before each word, a cross will appear on the screen. Please focus your gaze on it. If the instructions are clear, press the space bar and the study will begin immediately."

The subjects could also, if necessary, correct their answer until the next task appeared, which made it possible to include the number of corrections as a variable in the study.

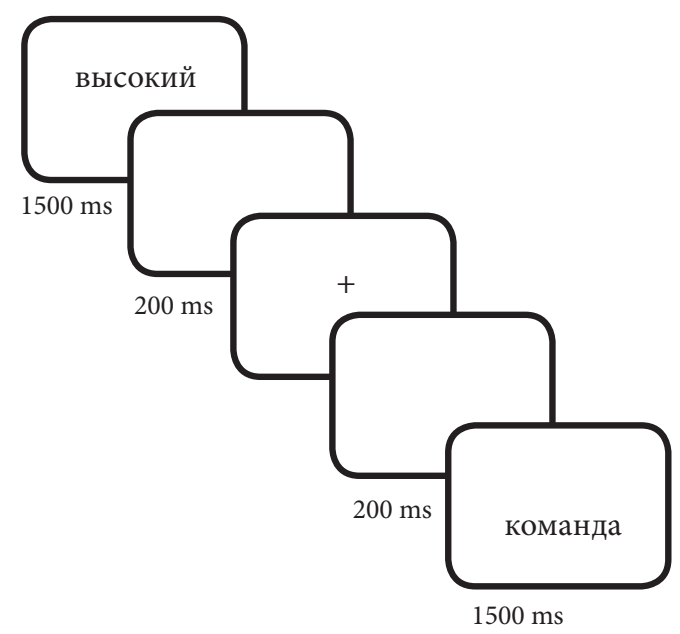

Figure 1. Procedure for presenting stimuli, specifying the duration of each stage

Note. вьсокий [vsokii] [correct word: высокий — vysokii — high];

команда [komanda] [spelling is correct - team]

\section{Study participants}

The study involved 31 first-year students from Saint Petersburg State University, all native speakers of Russian, of whom 21 were girls ( $67.74 \%$ of the total) and 10 were boys $(32.26 \%)$. The average age was 18.99 years.

\section{Data processing}

Statistical data were processed in STATISTICA 8 in the paradigm of event-related potentials (General Linear Models) and IBM SPSS Statistics 22 (descriptive statistics [mean, standard deviation]; non-parametric methods for comparison of independent samples (U Mann-Whitney criterion); correlation analysis (Spearman's rank correlation coefficient).

Processing of ERP data included a filtration procedure: automatic removal of EOG in the WinEEG program and manual cleaning of artifacts. After preliminary processing of the EEG recordings, as well as exclusion of incorrect choices, the average number of tests for each subject used for averaging was 92 for stimulus words containing an error and 95 for those without an error. 
The amplitude (in microvolts) of the components of the averaged ERPs was calculated from the baseline to the maximum of each component. The latent period component of the averaged ERPs for the presentation of each stimulus was calculated from the moment the stimulus was presented.

\section{Results}

The differentiation of the subjects based on academic success was based on three criteria: the results of the Russian-language USE, the average score on the USE, and the average grade for the winter term. Subjects whose criterion value exceeded $(M+1 / 4 \sigma)$ were placed in the more successful group, and those whose value was less than $(\mathrm{M}-1 / 4 \sigma)$ were in the less successful group. All who were in the average zone were excluded from further analysis. It is important to point out that the sample generated from the SPbSU first-year students who had enrolled in 2016 is characterized by greater academic success than in the country as a whole and even in Saint Petersburg. The average score on the Russian-language USE was $90.67 \sigma=7.35)$; the USE score for two specialized subjects was $82.68(\sigma=7.55)$. For comparison, the average score on the Russian-language USE in 2016 in St. Petersburg was 71.61 points, and in the Russian Federation as a whole it was 67.5; in mathematics for intended STEM majors - 47.83 points in St. Petersburg (according to the official portal of the state final certification of graduates of grades 9 and 11 in St. Petersburg for 2017) and 46.3 points in Russia as a whole (according to the official USE portal).

The number of groups obtained and their gender composition are presented in Table 2 .

Table 2. Number of groups with different levels of academic success

\begin{tabular}{ccccccc}
\hline \multirow{2}{*}{ Differentiating criterion } & \multicolumn{3}{c}{ Less successful } & \multicolumn{3}{c}{ More successful } \\
\cline { 2 - 7 } & Boys & Girls & Total & Boys & Girls & Total \\
\hline USE average & 3 & 10 & 13 & 4 & 9 & 13 \\
Russian-language USE & 6 & 6 & 12 & 2 & 13 & 15 \\
Academic term & 5 & 8 & 13 & 4 & 11 & 15 \\
\hline
\end{tabular}

\section{Analysis of success in finding errors and speed of response}

Analysis of pair correlations using Spearman's criterion revealed a weak negative correlation $(\mathrm{r}=-0.373, \mathrm{p}=0.039)$ between the results of the Russian-language USE and the number of errors made when solving the experimental problems. However, comparison of the groups of students with different levels of academic success did not reveal any significant differences in their ability to find errors.

As Table 3 shows, subjects made the most errors $(41.2 \%$ of the total number of errors) when the task contained stimuli of the third type (replacement of a letter with one similar in appearance) and the least errors $(12.32 \%)$ in the second type (words containing a typo - replacement of a letter with one that is dissimilar both in appearance and in sound). Problems with spelling mistakes because of the 
replacement of a letter with one that sounds similar proved to be quite difficult $30.42 \%$ of the mistakes were made in this type of problem.

Table 3. Distribution of incorrectly solved problems, depending on the type of stimulus

\begin{tabular}{cccccc}
\hline $\begin{array}{c}\text { Type of } \\
\text { stimulus }\end{array}$ & $\begin{array}{c}\text { Number of } \\
\text { incorrectly } \\
\text { solved problems }\end{array}$ & $\begin{array}{c}\text { Number of } \\
\text { correctly solved } \\
\text { problems }\end{array}$ & Total & $\begin{array}{c}\text { \% with errors out } \\
\text { of all the problems } \\
\text { of the same type }\end{array}$ & $\begin{array}{c}\text { \% of all } \\
\text { errors }\end{array}$ \\
\hline 1 & 79 & 944 & 1.023 & 7.72 & 30.42 \\
2 & 32 & 991 & 1.023 & 3.13 & 12.32 \\
3 & 107 & 916 & 1.023 & 10.46 & 41.21 \\
4 & 125 & 2.944 & 3.069 & 4.07 & 16.05 \\
Total & 343 & 5.795 & 6.138 & 5.59 & 100 \\
\hline
\end{tabular}

Analysis of the speed of motor response given the correct solution to the experimental task showed that the response time for tasks of the first type (a spelling error in which a letter has been replaced with another that sounds similar) significantly exceeded the response time for the other tasks ( $p=0.013$ between stimulus types 1 and $2, p=0.044$ between types 1 and 3 , and $p=0.001$ between types 1 and 4 ). No differences were found in the speed of solving problems of the second, third, and fourth types.

\section{Comparative analysis of psychological features of students with different levels of academic success}

Comparative analysis of the groups of students with different levels of academic success using the nonparametric U Mann-Whitney criterion revealed significant differences in the development of the components of the system of self-management, in the indicators "Goal-Setting" and "Forecasting," as expressed by the personality trait "Emotionality" (Big Five), and in the number of corrections made to answers given for the experimental problems. Table 4 shows that students with a higher average USE score have, on average, a more developed ability to create a subjective model of what is desired or correct, than students with lower results. The students who were more successful in the Russian-language USE were more relaxed, confident, emotionally mature, and more often stopped at their first choice of answer than those who are less successful. Subjects who received higher grades during the academic term were less likely to change their answers to the experimental problems and were less able to speculate on possible further developments based on analysis of the past and present.

Differences in the statistical trend when comparing groups of students with different levels of academic success were identified by the variables "Planning" to differentiate the results of the academic term $(p=0.065)$ and "Goal-Setting" to differentiate the Russian-language USE scores $(\mathrm{p}=0.093)$. The less successful students showed a lower level of development of both of these stages of the self-management system, compared to the more successful ones. 
Table 4. Intergroup psychological differences between students with more and less academic success

\begin{tabular}{ccccc}
\hline \multirow{2}{*}{$\begin{array}{c}\text { Criterion } \\
\text { of success }\end{array}$} & Variable & \multicolumn{2}{c}{ Average value } & $\begin{array}{c}\text { U Mann- } \\
\text { Whitney } \\
\text { criterion }\end{array}$ \\
\cline { 3 - 4 } & Goal-Setting & $\begin{array}{c}\text { Less } \\
\text { successful }\end{array}$ & $\begin{array}{c}\text { More } \\
\text { successful }\end{array}$ & 0.009 \\
\hline USE average & 2.231 & 3.692 & 0.004 \\
\hline $\begin{array}{c}\text { Russian- } \\
\text { language USE }\end{array}$ & Emotionality - Restraint & 55.000 & 44.267 & 0.032 \\
\hline $\begin{array}{c}\text { Academic } \\
\text { term }\end{array}$ & Number of corrections & 7.000 & 3.933 & 0.037 \\
\hline
\end{tabular}

Note. Average value - points on a scale. On Peysakhov's SMA, the range is from 0 to 6; on the Big Five-factor scale, it is from 15 to 75 .

\section{Neurophysiological indicators for solving experimental problems: Searching for errors}

To study the differences in neurophysiological cognitive control in students with different levels of academic success, using STATISTICA 8 with the General Linear Models method, we analyzed the data obtained for problems correctly solved by the subjects with stimulus types 1 to 3 (words with errors) and type 4 (correctly spelled words). The answers for types 1,2, and 3 were averaged, as there were no significant differences among them.

The following were allocated as components related to cognitive control (Kropotov, 2010): a component of motor response suppression and conflict monitoring N2 (N200), a component involving the P3b (part of the P300 complex), an N400 component for monitoring of activity. These, as some sources note (Kutas \& Federmeier, 2011; Deacon et al., 2004), have a maximum intensity in the centro-parietal leads $(\mathrm{Pz})$. The data obtained from the Pz lead in the range from 120 to $440 \mathrm{~ms}$ was most significant for the further processing.

Figure 2 shows the ERPs for the correctly and incorrectly spelled words (average for all types of errors). The graph shows the differences between the curves for ERP at one of the sections of interest to us - from 320 to $440 \mathrm{~ms}$ (that is, in the N400 region) - the amplitude of the potentials caused by incorrectly written words was significantly greater $(\mathrm{p}<0.001)$ than for those spelled correctly. These data are consistent with the hypothesis that N400 is generated by orthographic / phonological analysis and is attenuated by top-down processes of feeding semantic information to the orthographic / phonological level (Deacon, et al., 2004).

The curves of event-related potentials of the less successful (Group 1) and more successful subjects (Group 2), obtained in lead $\mathrm{Pz}$, are presented in Figure 3 (grouped according to the average USE score), Figure 4 (grouped according to the results of the Russian-language USE), and Figure 5 (grouped by success - the result of the academic term). The figures on the left show dynamics of electrical brain activity in response to words containing an error, and on the right, to correctly written words. 


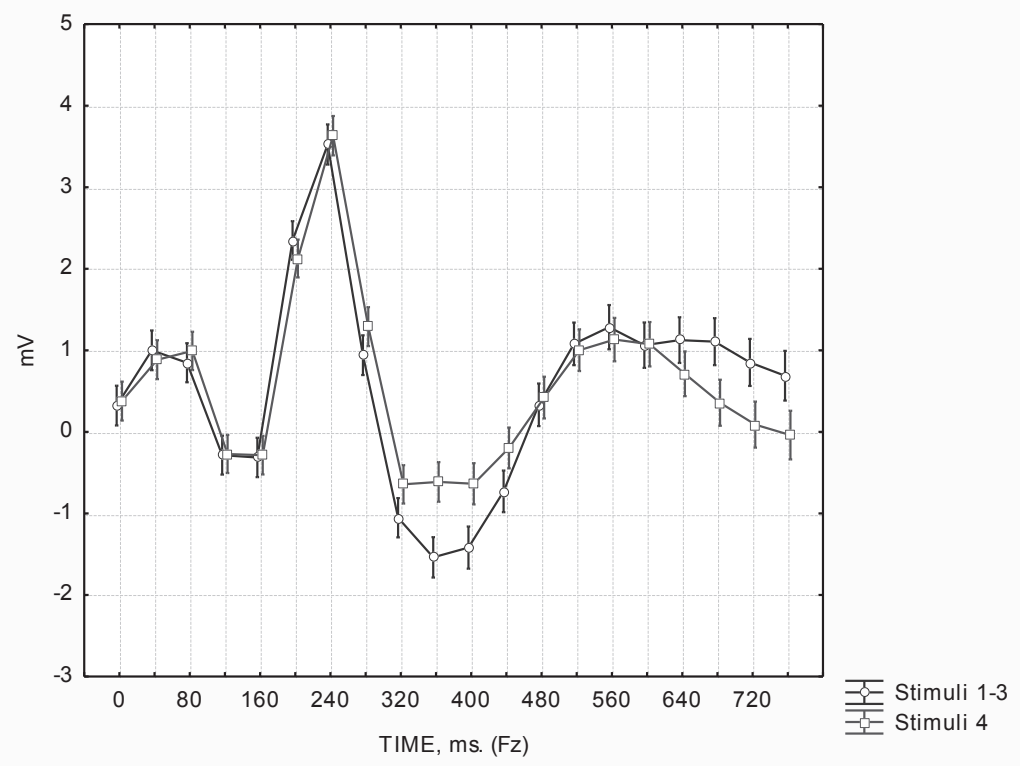

Figure 2. ERPs in response to stimuli containing an error (blue line) / not containing an error (red line)

Students with lower academic success, measured by their average result on the USE, were found to have a greater amplitude of the positive wave in the region of around $160 \mathrm{~ms}(\mathrm{p}<0.01)$ and a smaller one in the region of $280-320 \mathrm{~ms}(\mathrm{p}<0.001)$; those less successful on the Russian-language USE had smaller amplitudes of the $\mathrm{N} 200$ components $(240 \mathrm{~ms})(\mathrm{p}<0.01)$ and $\mathrm{P} 3 \mathrm{~b}(280-320 \mathrm{~ms})(\mathrm{p}<0.001)$ and greater latency of the $\mathrm{N} 400$ component $(\mathrm{p}<0.001)$; for those less successful in the term, there were larger amplitudes of the positive wave in the region around $160 \mathrm{~ms}$ in response to correctly spelled words $(\mathrm{p}=0.026)$ and a negative wave in the region of $240 \mathrm{~ms}(\mathrm{p}<0.01)$ in response to stimuli of any kind, compared to the more successful subjects.
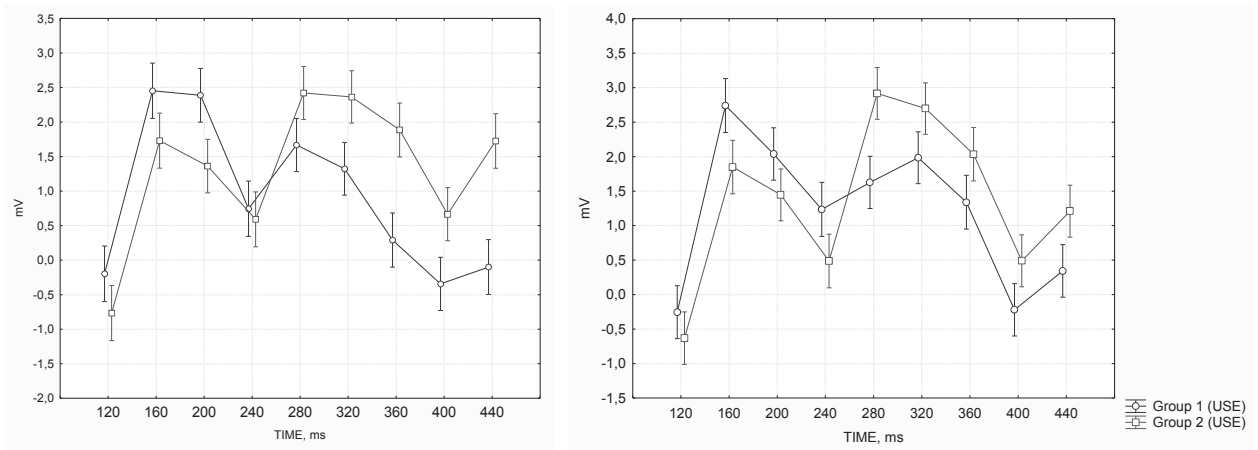

Figure 3. ERPs in response to the presentation of stimuli with an error (left) and without an error (right) obtained in lead $\mathrm{Pz}$ in groups of students with lower (blue line) and higher (red line) results on the USE 

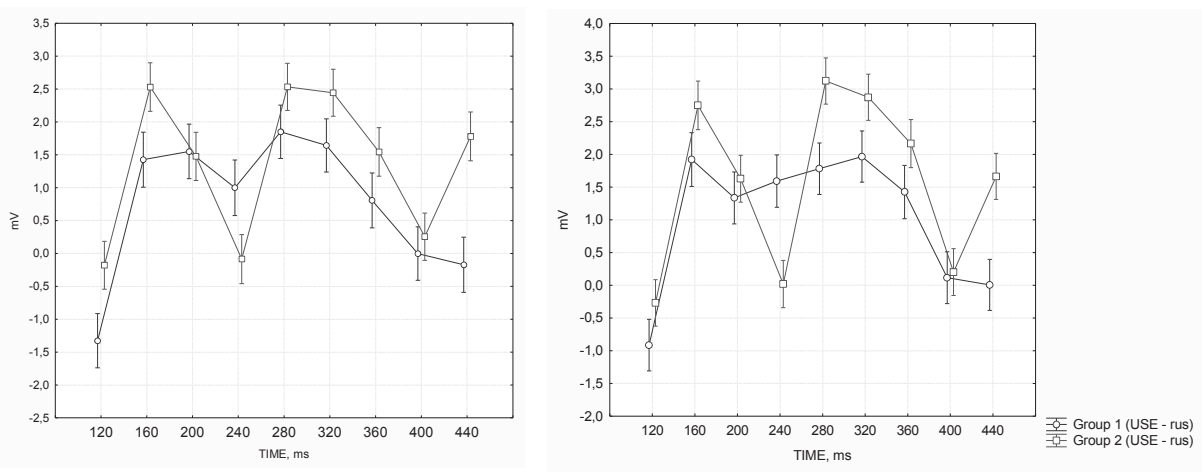

Figure 4. ERPs in response to the presentation of stimuli with an error (left) and without an error (right) obtained in lead $P z$ in groups of students with lower (blue line) and higher (red line) results on the Russian-language USE
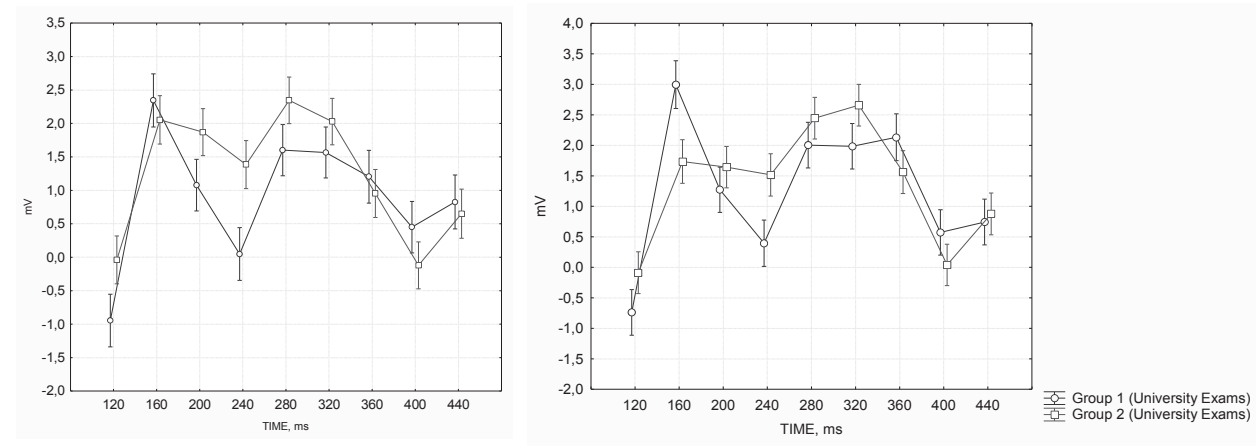

Figure 5. ERPs in response to the presentation of stimuli with an error (left) and without an error (right), obtained in lead Pz in groups of students with lower (blue line) and higher (red line) results in the academic term

Summing up the results, we can say that academic success has key interrelationships with all the types of data measured: with personal characteristics, components of the self-management system, behavioral experimental data, and neurophysiological indicators for solving experimental problems. Students with a higher level of academic success displayed lower values on the scales of "Emotionality" of the five-factor personality questionnaire and "Forecasting" on the "Self-Management Ability" scale, and higher values on the scales of "Planning" and "Goal-Setting," and made fewer corrections when solving the experimental problem, compared with less successful students. The differences between the neurophysiological indicators of cognitive control are displayed in the characteristics of the P200, N200, P300, and N400 components.

\section{Discussion}

Although the tasks of the first type (one of the letters is replaced with another than has a similar sound) were the most difficult from the point of view of speed of performance, we found that students missed errors of any type, and the majority of replaced letters that went unnoticed looked similar to the correct letter (type 3 ). 
The negative relationship found in our study between academic success and the Big Five factor associated with emotional self-control is confirmed by data from both foreign (Poropat, 2009) (meta-analysis) and Russian studies. In particular, A.A. Vorobyeva's study (2015) identified the interrelationship of academic success of students with all the factors of the "Big Five" except for Agreeableness. A study by E.V. Kochergina et al. (2013) with a Russian population sample showed an interrelationship of the "Big Five" factor relating to emotions, and the results of the Russian-language USE; however, the curve is inverse: the greater the subject's Emotionality, the higher the score on the USE, and vice versa. The authors explain the discrepancy between their results and those of researchers abroad by the differences in the educational environments in different countries. We suggest, however, that the inverse correlation of emotionality and the USE results may be related to the fact that the exam situation, which in itself is stressful, combined with high emotional lability, can negatively affect the educational process.

Many authors (Konopkin \& Pryigin, 1984; Ishkov, 2004; Osnitskiy, 2009) also stress the importance of the development of all components of the system of selfmanagement for educational success, including for taking the USE (Morosanova et al., 2014). They note that the higher the student's level of conscious self-regulation of his educational work, the greater his academic success, and vice versa. In our study, the more successful subjects were characterized by a higher level of the Planning and Goal-Setting components, and a lower level of Forecasting, compared to the less successful. This is demonstrated when the subjects were split into groups according to their success in the academic term, and could be explained by the fact that higher education is a new situation for recent schoolchildren, with new types of work, increased workload, less adult supervision, the need to organize one's own academic and extracurricular time, and, consequently, it requires completely different ways of operating. The way the student has obtained high grades in school no longer works, and students who are more accustomed to make forecasts based on past experience find themselves less flexible in the new environment.

Summarizing the comparative analysis of the brain's functional activity in firstyear students with different levels of academic success, we can conclude that firstyear students who were more successful on the USE have lower P200 amplitude, higher N200 and P300 amplitude, as well as lower N400 latency (characteristic only of language competence) when performing the experimental task, than those whose results on the school graduation exams were worse. This may indicate that the former pay more attention and are more engaged in the process of finding errors. On the other hand, flexible regulation of one's cognitive processes and allocation of effort depending on the difficulty of the task play a great role in success at university.

The literature contains evidence that the amplitude of the P200 component, which peaks at 150-250 ms, decreases with increasing attention (Crowley \& Colrain, 2004), while the amplitude of the P3b component (with a latency of about 300 $\mathrm{ms}$ ) increases (Gordeev, 2007). The amplitude of the N200 component is positively correlated with cognitive control, but it is still unclear with which particular executive function (Lamm et al., 2006). The N400 component is characterized by high temporal stability. One of the few factors that can affect the latency of this variable 
is the language experience of the subject (Federmeier \& Laszlo, 2009) - the greater it is, the less the latency of N400.

Thus we can conclude that subjects who were less successful on the USE have a lower level of attention and cognitive control compared to those who were more successful.

The results obtained in analyzing the differences between students who received higher and lower grades for the first term turned out to be contradictory. On the one hand, the more successful subjects showed smaller N200 amplitudes, which could be a sign of lower cognitive control. On the other, when solving problems that do not contain an error, the amplitude of the positive wave around $160 \mathrm{~ms}$ in the more successful students was lower, indicating greater attention compared to the less successful students. We hypothesize that the generally low level of activity of the controlling system with its selective increase allows students to cope with the greater educational burden that results from the transition from school to university.

\section{Conclusion}

Our research allows us to draw the following conclusions about the interrelationship of cognitive control and academic success:

- first-year students with a higher level of academic success are characterized by less emotionality, are better at goal-setting but not as good at forecasting; they also less often change their initial answer to an experimental problem than do less successful students;

- students who were more successful on the USE have lower P200, higher N200 and P300, as well as lower N400 latency (characteristic only for the Russian-language section of the USE) when performing the experimental task than those whose results were worse on school graduation exams. This indicates that they pay more attention and are more engaged in the process of finding errors. However, in the differences among first-year students, those both more and less successful in the academic term, the difference in ERP characteristics played a greater role not between groups in exam results, but within groups depending on the problem.

Overall, the three-level analysis of the controlling function in students permits a conclusion on the cross-cutting nature of its manifestations. Greater difficulty in looking for errors in words with similar spelling indicates that missing errors is not particularly related to knowledge of orthography. The obstacle is the similarity of visual word forms, the optical proximity of graphemes, which makes it more difficult to compare a word with the standard. But a high level of development of the self-regulation and self-management system potentially improves the process of finding an error. Neurophysiological support for this process is also related to the flexibility of the management system, the need to vary the concentration of attention from a lower level (weakening of concentration), when an error is obvious ("jumps out at you"), to a sharp increase when a correctly written word is being checked (a "non-obvious" error, so you have to look closely for it). 
The results of the present research indicate an insufficient level of self-control for finding errors in words, primarily when letters are replaced with others that are similar in appearance or in sound. Knowledge of the rules of spelling and grammar in the Russian language does not prevent spelling mistakes. We conclude, therefore, that more attention should be paid in the educational process to the development of cognitive control. We recommend teaching aids to improve pupils' validation skills, based not only on the rules of orthography, but also on any other mismatch with the correct spelling of the word. For example, tasks including errors in words because of extra or missing letters or letters that are similar in appearance or pronunciation.

\section{Limitations}

Considering that the sample was not controlled for gender, the results may have limitations that require further verification of intersexual differences in the neurophysiological basis of cognitive control.

\section{Acknowledgements}

This work was supported by a grant of the Government of the Russian Federation, "Cognitive neurobiology of the processes of learning and perception of language," Project No. 14. W03.31.0010.

Translated by Susan Welsh, welsh_business@verizon.net

\section{References}

Anokhin, P.K. (1975). Ocherki po fiziologii funktsionalnykh sistem [Essays about the physiology of functional systems]. Moscow: Meditsina.

Bernstein, N.A. (1990). Fiziologiya dvizheniy i aktivnost [Physiology of movement and activity]. Moscow: Nauka.

Cartwright, K.B. (2012). Insights from cognitive neuroscience: the importance of executive function for early reading development and education. Early Education and Development, 23(1), 24-36. doi: 10.1080/10409289.2011.615025

Crowley, K.E., \& Colrain, I.M. (2004). A review of the evidence for P2 being an independent component process: Age, sleep and modality. Clinical Neurophysiology, 115(4), 732-744. doi: 10.1016/j.clinph.2003.11.021

Davydov, V.V. (1986). Problemy razvivayushchego obucheniya: Opyt teoreticheskogo i eksperimentalnogo psikhologicheskogo issledovaniya [Problems of developmental learning: theoretical and experimental research experience]. Moscow: Pedagogika.

Deacon, D., Dynowska, A., Ritter, W., \& Grose-Fifer, J. (2004). Repetition and semantic priming of nonwords: Implications for theories of N400 and word recognition. Psychophysiology, 41, 60-74. doi: 10.1111/1469-8986.00120

Diamond, A. (2013). Executive functions. Annual Review of Psychology, 64, 135-168. doi: 10.1146/annurev-psych-113011-143750

Elkonin, D.B. (1974). Psikhologiya obucheniya mladshego shkolnika [Psychology of young pupils' learning]. Moscow: Znaniye.

Espy, K., McDiarmid, M.D., Cwik, M.F., Stalets, M.M., Hamby, A., \& Senn, T.E. (2004). The contribution of executive functions to emergent mathematic skills in preschool children. Developmental Neuropsychology, 26(1), 465-486. doi: 10.1207/s15326942dn2601_6 
Federmeier, K.D., \& Laszlo, S. (2009). Time for meaning: Electrophysiology provides insights into the dynamics of representation and processing in semantic memory. In B. H. Ross (Ed.), Psychology of learning and motivation, 51 (pp. 1-44). Burlington: Academic Press. doi: 10.1016/S0079-7421(09)51001-8

Friedman, N.P., \& Miyake, A. (2017). Unity and diversity of executive functions: Individual differences as a window on cognitive structure. CORTEX, 86, 186-204. doi: 10.1016/j.cortex.2016.04.023

Gilmore, C.K., \& Cragg, L. (2014). Teachers' understanding of the role of executive functions in mathematics learning. Mind, Brain, and Education, 8(3), 132-136. doi: 10.1111/mbe.12050

Gordeev, S.A. (2007). Primenenie metoda endogennyikh svyazannyikh s sobyitiyami potentsialov mozga P300 dlya issledovaniya kognitivnyih funktsiy v norme i klinicheskoy praktike. [Application of the method of endogenous event-related brain potentials P300 to the study of cognitive functions in norm and clinical practice]. Fiziologiya cheloveka [Human physio$\log y], 33(2), 121-133$.

Ishkov, A.D. (2004). Uchebnaya deyatelnost studenta: psikhologicheskie faktoryi uspeshnosti [The student's educational activities: Psychological factors of success]. Moscow: ASV.

Kochergina, E.V., Nye, J.V.C., \& Orel, E.A. (2013). Faktoryi "Bolshoy pyaterki” kak psikhologicheskie prediktoryi akademicheskoy uspevaemosti studentov vuzov [Factors of the "Big 5" as psychological predictors of academic performance of students in higher education]. Psikhologicheskie issledovaniya [Psychological Studies], 6(27), 4.

Konopkin, O.A., \& Pryigin, G.S. (1984). Svyaz uchebnoy uspevaemosti studentov s individualno-tipologicheskimi osobennostyami ikh samorealizatsii [Relation of students' academic performance with individual typological features of their self-realization]. Voprosyi psikhologii [Issues in Psychology], 3, 42-53.

Kostromina, S.N., Bordovskaya, N.V., Iskra, N.N., Chuvgunova, O.A., Gnedykh, D.S., \& Kurmakayeva, D.M. (2015). Neyronauka. psikhologiya i obrazovaniye: problemy i perspektivy mezhdistsiplinarnykh issledovaniy. [Neuroscience, psychology and education: problems and perspectives of interdisciplinary research]. Psikhologicheskiy zhurnal [Psychological Journal], 36(4), 61-70.

Kropotov, Yu.D. (2010). Kolichestvennaya EEG. Kognitivnyye vyzvannyye potentsialy mozga cheloveka i neyroterapiya [Quantitative EEG. Cognitive event-related potentials of human brain and neurotherapy]. Donetsk, Ukraine: Zaslavskiy, A.Yu.

Kutas, M., \& Federmeier, K.D. (2011). Thirty years and counting: finding meaning in the N400 component of the event-related brain potential (ERP). Annual Review of Psychology, 62, 621-647. doi: 10.1146/annurev.psych.093008.131123

Lamm, C., Zelazo, P.D., \& Lewis, M.D. (2006). Neural correlates of cognitive control in childhood and adolescence: Disentangling the contributions of age and executive function. $\mathrm{Neu}$ ropsychologia, 44(11), 2139-2148. doi: 10.1016/j.neuropsychologia.2005.10.013

Lesh, T.A., Westphal, A.J., Niendam, T.A., Yoon, J.H., Minzenberg, M.J., Ragland, J.D., Solomon, M., \& Carter, C.S. (2013). Proactive and reactive cognitive control and dorsolateral prefrontal cortex dysfunction in first episode schizophrenia. Neuroimage: Clinical, 2, 590599. doi: 10.1016/j.nicl.2013.04.010

Morosanova, V.I., Filippova, E.V., \& Fomina, T.G. (2014). Lichnostnyie i regulyatornyie prediktoryi uspeshnosti i nadezhnosti deystviy shkolnikov v situatsii ekzamena [Personal and regulatory predictors of the success and reliability of the actions of schoolchildren in an exam situation]. Vestnik moskovskogo universiteta. Seriya 14. Psikhologiya [Moscow University Psychology Bulletin], 4, 4-17. 
Nunes, T., Bryant, P., Barros, R., \& Sylva, K. (2012). The relative importance of two different mathematical abilities to mathematical achievement. British Journal of Educational Psychology, 82(1), 136-56. doi: 10.1111/j.2044-8279.2011.02033.x

Osnitskiy, A.K. (2009). Regulyatornyiy opyit, sub'ektnaya aktivnost i samostoyatelnost cheloveka. Chast 2 [Regulatory experience, subjective activity and individual autonomy. Part 2]. Psikhologicheskie issledovaniya [Psychological Studies], 6(8). Retrieved from http://psystudy. ru/index.php/num/2009n6-8/241-osnitsky8.html

Pavlov, I.P. (1973). Dvadtsatiletniy opyt obyektivnogo izucheniya vysshey nervnoy deyatelnosti (povedeniya) zhivotnykh [Twenty years of experience in objective investigation of animals' higher nervous activity (behavior)]. Moscow: Nauka.

Poropat, A. (2009). A meta-analysis of the Five-factor model of personality and academic performance. Psychological Bulletin, 135(2), 322-338. doi: 10.1037/a0014996

Rean, A.A. (Ed.) (2002). Psikhologiya cheloveka ot rozhdeniya do smerti [Human psychology from birth to death]. St. Petersburg, Russia: PRAYM-EVROZNAK.

St Clair-Thompson, H.L., \& Gathercole, S.E. (2006). Executive functions and achievements in school: shifting, updating, inhibition, and working memory. Quarterly Journal of Experimental Psychology, 59(4), 745-59. doi: 10.1080/17470210500162854

Steele, A., Karmiloff-Smith, A., Cornish, K., \& Scerif, G. (2012). The multiple subfunctions of attention: differential developmental gateways to literacy and numeracy. Child Development, 83(6), 2028-2041. doi: 10.1111/j.1467-8624.2012.01809.x

Stuss, D.T., \& Knight, R.T. (2002). Principles of frontal lobe function. New York: Oxford University Press. doi: 10.1093/acprof:oso/9780195134971.001.0001

Thorell, L.B. (2007). Do delay aversion and executive function deficits make distinct contributions to the functional impact of ADHD symptoms? A study of early academic skill deficits. Journal of Child Psychology and Psychiatry, 48(11), 1061-1070. doi: 10.1111/j.14697610.2007.01777.x

Vorobeva, A.A. (2015). Volevyie i poznavatelnyie chertyi lichnosti kak faktoryi uchebnyikh dostizheniy studentov [Volitional and cognitive features of personality as factors of students' educational achievements]. Moscow: RUDN.

Welsh, J.A., Nix, R.L., Blair, C., Bierman, K.L., \& Nelson, K.E. (2010) The development of cognitive skills and gains in academic school readiness for children from low-income families. Journal of Educational Psychology, 102(1), 43-53. doi: 10.1037/a0016738

Original manuscript received July 26, 2017

Revised manuscript accepted October 23, 2017

First published online November 30, 2017 